\title{
Organization of Urban Transport Organization - Presentation of Bicycle System and Bicycle Infrastructure in Lublin
}

\author{
Agnieszka Dudziak ${ }^{1}$ and Jacek Caban ${ }^{2 *}$ \\ ${ }^{1}$ University of Life Sciences in Lublin, Faculty of Production Engineering, 28 Gleboka Str., 20-612 \\ Lublin, Poland; E-mail: agnieszka.dudziak@up.lublin.pl \\ ${ }^{2}$ Lublin University of Technology, Faculty of Mechanical Engineering, 36 Nadbystrzycka Str., 20- \\ 618 Lublin, Poland; E-mail: j.caban@pollub.pl
}

*Corresponding Author: Jacek Caban

Received: 3 November 2020; Revised: 18 January 2021; Accepted: 8 February 2021; Published: 21 May 2021

\begin{abstract}
The introduction of a city bike system, which has become a complement to the public transport system in large cities and mainly in the most crowded city centers, seems to be a very good solution, which may contribute to reducing urban congestion, air pollution, and noise level. In many situations, bicycle transport can solve the deficiencies in public transport, e.g. at nights, during holidays and on days when bus services are operated to a limited extent. The article presents the functioning of the city bike system in Lublin implemented at the end of 2014, including basic information on the system, its advantages and disadvantages, as well as the existing infrastructure and development prospects.
\end{abstract}

Keywords: City logistics, public transport, bicycle rental

\section{Introduction}

The highest concentration of traffic is in large cities and whole agglomerations [1]. Public transport is operated to satisfy the transport needs of persons, especially vulnerable groups of people, pupils, students, and pensioners as well as workers [2]. However, urban transport is not the only form of mobility. It should be emphasized that the ecological awareness of city dwellers is constantly growing, which leads them to decide for alternative forms of travelling. The most popular ones include, for example, bicycle, car sharing, or walking. One of sustainable transport options consists in using non-motorized transportation - cycling, or including cycling in urban transport $[3,4]$. New regulations of the European Union enforce the limitation of the impact on the environment, which is reflected in restrictions imposed on car traffic in city centers and the renaissance of trolleybuses [5]. Importantly, the inflow of EU funds contributed to the development of transport infrastructure 
throughout Poland. New sources of financing also forced new forms of management and innovative infrastructure solutions. One of the manifestations of this situation is the construction of numerous bicycle paths which, apart from recreational, are used as a form of alternative urban mode of transport. The introduction of the city bike system as a complement to the public transport system in large agglomerations and mainly in the most crowded city centers, appears to be a very good solution, which may contribute to reducing air pollution [6-13], noise levels [14,15], the occurrence of transport congestion [16-21]. Poliak et al. [22] present the issues of social legislation in road transport as a means to ensure safe road transport. In turn, Kampf et al. [23] studied the macroeconomic evaluation of projects concerning transportation structures and facilities. Cycle transport represents a mode of transport that has efficient transport requirements especially for short as well as long distances [4]. Research into bicycle level-of-service (BLOS) has been extensively conducted in recent years [24,25]. This research is mostly focused on user perceptions of comfort [26-28] to provide guidance for decision-makers and planners [17,29-33] and city databases [34]. Recently, there has been an increase in interest in electric mobility, including both bicycles [35] and cars [5,12,36]. Electric drivetrain is particularly suitable in vehicles with high annual mileage, such as city buses operating in public transport [37].

This objective of this paper is to present the functioning of the city bike system in the city of Lublin, located in south-eastern Poland, including basic information on this system as well as the existing infrastructure and development prospects. An additional aspect discussed in this study is the epidemic situation in the country, which has demonstrably affected many areas of life, including the operation of the Lublin City Bike system.

\section{Ways of Traveling in an Urban Agglomeration}

A typical feature of current urban development is immense growth of towns caused by the creation of industrial zones, shopping and amusement parks, and residential zones [38]. The main purpose of transport is to meet this growth by appropriate means. A specific form of transport is urban transport, which, according to horizontal classification, can be divided based on the criteria of range and distance into territorial units within which individual transport operations are performed [39]. It consists mainly in the provision of transport services within cities and suburban areas. In addition, it has a direct impact on urban development of cities. One of its forms is the so-called public transport ensured mainly by buses, trolleybuses, trams, and metro. The choice of a specific means of transport is influenced by many factors, such as its availability, safety, travel comfort, personal preferences of travelers $[38,40]$. The final choice is always made subjectively. Changing habits is possible but requires a long time and consistent actions [28]. The creation of an efficient public transport system that would meet the expectations of inhabitants is one of the key tasks for the boards of territorial 
units [41]. Currently, the main goal of such a system is to reduce congestion and the negative effects it causes, and to minimize the number of road accidents. Drivers and their personality traits play a significant role in the occurrence of risk situations and problems while driving on public roads [42]. As already mentioned, the ecological awareness of city dwellers is increasing, which results in using alternative forms of transport, e.g. bicycle, scooter, car sharing, or walking.

\section{Data and Methods}

The aim of the paper is to describe the functioning of the city bike system in Lublin implemented at the end of 2014, and the prospects for its further development. The paper includes a short analysis of data from bicycle rentals in the years 2014-2020 provided by the operator of this system. In addition, the paper presents the basic information about this system, its advantages and disadvantages as well as the existing infrastructure.

\section{Lublin's Communication Infrastructure}

Lublin is an example of a city whose road network in many places is difficult to solve, e.g. due to past urban planning errors, location on hills, or unfavorable soil and water conditions which require high investments in the road network [43]. As in most Polish cities, the road network has a radialring character. Such an arrangement developed naturally along with the development of the city around the center.

The weaknesses of the current road system include:

- inefficiency of basic routes (their standard and technical parameters do not correspond to the existing traffic volume),

- insufficient capacity of some streets,

- insufficiently developed system of ring roads and their non-uniform standard,

- ambiguity of the road system (duplication of ring roads by lower class roads in the downtown area),

- poor technical condition of streets and road facilities, which causes low travel comfort,

- missing modern, intelligent traffic management system,

- $\quad$ no $\mathrm{P}+\mathrm{R}$ (park \& ride), $\mathrm{B} \& \mathrm{R}$ (bike \& ride) parking system for people commuting to Lublin by car or bicycle.

The strengths include:

- Lublin's location in an important communication node,

- a developed long-distance road network,

- a developed and modern/sophisticated? urban public transport system,

- introduction of paid parking zones in the centre, 
- $\quad$ progress in adapting the public transport system and road infrastructure to the needs of disabled people,

- construction of the traffic management system has been started [43].

In recent years, the city of Lublin has made many investments. They include the construction of new roads and the renovation and reconstruction of existing urban roads. The common feature of the works carried out is the investment not only in improving the possibility for drivers of passenger cars but also for public transport and cyclists. New cycle paths, bus lanes and locks for buses departing from bus stops are being built. The city also makes significant investments in the modernization and expansion of trolleybus traction. These investments are in line with the Low Emission Economy Plan for the city of Lublin (trolleybuses are zero-emission vehicles, reconstruction of key intersections such as national roads 12,17, 19 (Sikorskiego Av., Solidarności Av.) and Voivodeship road 809 (Poligonowa and Ducha Street) or the extension of Bohaterów Monte Cassino Street to the Sławin junction along the Lublin-Warsaw national road should contribute to the reduction of congestion in the city. Implementation of traffic management system is expected to increase the capacity of the road network, reduce the time loss in the road network, improve road safety, and positive effect on the environment by reducing emissions [43].

\section{Bicycle Infrastructure}

The development of the bicycle path network in the city is based on the Cycling Policy and the related documents including:

- Technical standards for the bicycle infrastructure of the city of Lublin valid from 2010 [44],

- $\quad$ Bicycle Policy of the city of Lublin valid from 2011 [45],

- Concept for the development of bicycle transport in the city of Lublin valid from 2011 [46],

- Strategy for the implementation of the bicycle road system in the city of Lublin valid from 2014 [47],

- $\quad$ Sustainable Mobility Plan for Lublin valid from 2015 [48].

This policy is implemented within the framework and respecting the principles of Lublin's Transport Policy and the city's spatial policy, and has a strategic goal of achieving a $15 \%$ share of bicycle traffic in the total number of roads in the city in 2025 [45]. Moreover, other partial goals are to be implemented, such as improving traffic safety, increasing the speed of movement within the city, promoting environmentally friendly transport behavior of the residents. It is recognized that the boom of cycling is associated with many environmental, economic, and social benefits (reduction of congestions, improve health, improved quality of living in the city due to reduced pollution and noise levels). The analysis of the differences in the popularity and importance of cycling in Lublin and in similar European cities shows a large development potential of this type of transport. Significant 
development of this mode of transport has been recorded especially in recent years. In 2013, there were approx. $70 \mathrm{~km}$ of pedestrian and bicycle routes in Lublin. According to the official website of the city of Lublin [49], in January 2017, it was approx. $140 \mathrm{~km}$. In 2020, the overall length of the cycle paths exceeded $170 \mathrm{~km}$.

In September 2014, a city bike rental system was launched. Initially, it included 40 stations with a total of 400 bicycles, which has currently expanded to 91 stations and 891 two-wheelers - including 5 stations and 41 bicycles in Świdnik (a nearby town) and 2 stations with 20 bicycles for children. Table 1 presents data on the operation of the Lublin City Bike system. The data for 2019 shows that the most common time for renting a bike (17\%) is between 3 p.m. and 5 p.m., i.e. when people return from work. The most numerous group - $45 \%$ of all registered users - are users aged 18-25 (i.e. approx. 50.8 thousand people) [50]. The second largest group of cyclists, the inhabitants of Lublin and Świdnik, are people aged 30 - 39 (almost $20 \%$ of approx. 22.1 thousand inhabitants). Seniors make up nearly $1.2 \%$ (about 1,350 ) of active city cyclists. .

Table 1 Statistics of Lublin City Bike. Source: author based on [51].

\begin{tabular}{cc}
\hline \multicolumn{1}{c}{ Season } & Rental \\
\hline $2014(19 / / 09 / / 2014-30 / 11 / 2014)$ & 128,644 \\
\hline $2015(21 / 03 / 2015-30 / 11 / 2015)$ & 436,965 \\
\hline $2016(21 / 03 / 2016-30 / 11 / 2016)$ & 784,737 \\
\hline $2017(21 / 03 / 2017-30 / 10 / 2017)$ & 502,337 \\
\hline $2018(21 / 03 / 2018-30 / 11 / 2018)$ & 637,953 \\
\hline $2019(21 / 03 / 2019-30 / 09 / 2019)$ & 457,896 \\
\hline $2020(21 / 03 / 2020-31 / 10 / 2020)$ & 8,611 \\
\hline
\end{tabular}

As seen from the table above, there was a continuous increase in the number of users interested in car rentals until 2016, reaching its maximum of almost 800,000 rentals. This applies to both the number of new system users and the number of rentals in the season. The following years show alternating increase and decrease in the interest in bike rental. The worst situation was in 2020 due to restrictions related to the SARS-Cov2 coronavirus, when the bire rental did not exceed the value of $10,000$.

\section{Advantages and Disadvantages of Bicycle Infrastructure}

The main advantages of Lublin's bicycle route network include: 
- use of attractive areas in the city (parks, green areas, riverside boulevards or the vicinity of the Zemborzycki Lake),

- good access to recreational areas around the city,

- allowing the so-called versus traffic on one-way roads in the centre.

The main disadvantages of the network include:

- insufficient continuity and consistency of the network,

- poor quality and technical condition of the pavement in older sections,

- poorly developed system of bicycle routes in the city centre,

- a small number of bicycle parking lots,

- lack of quality corridors between the most popular destinations and starting points to ensure the possibility of traveling between districts [47].

\section{Conclusion}

Cycling is a sustainable mode of transport; moreover, health benefits of cycling as an intensive physical activity are well known [52]. According to own research, the most common means of transport in Lublin is a passenger car. This may be due to a lack of infrastructure and some limitations of public transport (too small coverage in neighboring municipalities).

Almost one million Poles already use the city bike system, and rentals are counted in millions. To be fully efficient, the system needs an appropriate infrastructure, i.e. the optimal number of stations and bikes, as well as the appropriate logistics system. The lack of this type of facilities or solutions may decrease the attractiveness of cycling and limit the use of this mode of transport. A city bike is an ideal means of transport that significantly reduces travel time, partially relieving public transport and reducing the number of passenger cars on the road. The system's popularity is also influenced by its operating costs. Considering the experience of not only Polish but also European cities, each of them had different reasons for the implementation of the system. Some cities introduce this solution as a supplement to public transport, others because of the desire to maintain their status as a place for recreation and to reduce car traffic. In Lublin, the system was implemented as a part of the project "Lublin - the capital of cycling tourism", emphasizing the tourism potential of the region.

From the beginning of the Lublin city bike system operation, i.e. from 2014, until 2020, a total of over 3 million bikes were rented. The year 2016 was record-breaking in terms of the number of rentals, with 784,737 rentals. In the following years, the popularity of the city bike system in Lublin increased and decreased. A special year was the year 2020, which, due to the epidemic situation in the country, forced the reduction of bicycle stations services. Despite these difficulties, the system operated during the selected period of the year, but the level of bike rentals was only 8611 . However, based on the data analysis, it seems that reaching the value of 500,000 rentals in Lublin will be depend 
on the system stability and will be achieved in the coming years, provided that the epidemic situation is normalized. The city of Lublin still makes the road system more attractive by introducing a system of electric scooter rentals, but it is too early to estimate the impact of this means of transport on the Lublin city bike system. The presented article can be seen as an introduction to further detailed analyses.

\section{References}

[1] Sommerauerova, D., Chocholac, J. \& Urbanova, K. (2020). Sustainable green city logistic solution for the Prague agglomeration and retail chain. Perner's Contacts. 15(2). DOI: 10.46585/pernerscontacts.2020.15.1644.

[2] Dydkowski, G. \& Gnap, J. (2019). Premises and limitations of free public transport implementation. Communications - Scientific Letters of the University of Zilina. 21(4), 13-18. DOI: $10.26552 /$ com.C.2019.4.13-18.

[3] Rosca, E., Rusca, A., Ilie, A. \& Rusca, F. (2010). Non-motorized transportation - An educational challenge for urban communities. Theoretical and Empirical Researches in Urban Management. 8(8), 5-13.

[4] Moravčíková, K. \& Križanová, A. (2016). Corporate social responsibility focusing on the protection of the environment through the cycling transport. In Transport Means - Proceedings of the International Conference, 604-608.

[5] Dziubinski, M., Siemionek, E., Adamiec, M., Drozd, A. \& Kolodziej, S. (2017). Energy consumption of the trolleybuses. International Conference on Electromagnetic Devices and Processes in Environment Protection with Seminar Applications of Superconductors (ELMECO and AoS). IEEE Proceedings Paper. DOI: 10.1109/ELMECO.2017.8267723.

[6] Barta, D., Mruzek, M., Labudal, R., Skrucany, T. \& Gardynski, L. (2018). Possibility of increasing vehicle energy balance using coasting. Advances in Science and TechnologyResearch Journal. 12(1), 228-235. DOI: 10.12913/22998624/86215.

[7] Skrucany, T., Semanova, S., Figlus, T., Sarkan, B. \& Gnap, J. (2017). Energy intensity and GHG production of chosen propulsions used in road transport. Communications - Scientific Letters of the University of Zilina. 19(2), 3-9. Retrieved October 20, 2018, from http://komunikacie.uniza.sk/index.php/communications/article/view/174.

[8] Felkiewicz, M. \& Kubica, G. (2017). The influence of selected gaseous fuels on the combustion process in the SI engine. Transport Problems. 12(3), 135-146. DOI: 10.20858/tp.2017.12.3.13.

[9] Łebkowski, A. (2019). Studies of energy consumption by a city bus powered by a hybrid energy storage system in variable road conditions. Energies. 12(5), 951. DOI: 10.3390/en12050951.

[10] Rimkus, A., Zaglinskis, J., Stravinskas, S., Rapalis, P., Matijosius, J. \& Bereczky, A. (2019). Research on the combustion, energy and emission parameters of various concentration blends of hydrotreated vegetable oil biofuel and diesel fuel in a compression-ignition engine. Energies. 12(15), 2978. DOI: 10.3390/en12152978.

[11] Rodzeń, A., Stoma, M. \& Kuranc, A. (2018). Examination of vehicle exhaust gas analyzers in the context of the quality of periodic vehicle technical tests. Przemysł Chemiczny. 97(5), 762766. DOI: 10.15199/62.2018.5.22. 
[12] Skrucany, T., Kendra, M., Stopka, O., Milojevic, S., Figlus, T. \& Csiszár, C. (2019). Impact of the electric mobility implementation on the greenhouse gases production in central European countries. Sustainability. 11, 4948. DOI: 10.3390/su11184948.

[13] Šarkan, B., Gnap, J. \& Kiktova, M. (2019). The importance of hybrid vehicle in urban traffic in terms of environmental impact. The Archives of Automotive Engineering - Archiwum Motoryzacji. 85(3), 115-122. DOI: 10.14669/AM.VOL85.ART8.

[14] Figlus, T. \& Czachor, T. (2018). Preliminary studies of the effect of travelling speed and propulsion type on the sound level in the passenger compartment of a vehicle with a hybrid propulsion system. In 11th International Science and Technical Conference Automotive Safety 2018, 1-5. DOI: 10.1109/AUTOSAFE.2018.8373346.

[15] Skrucany, T., Šarkan, B., Figlus, T., Synak, F. \& Vrabel, J. (2017). Measuring of noise emitted by moving vehicles. Dynamics of Civil Engineering and Transport Structures and Wind Engineering (DYN-WIND'2017); MATEC Web of Conferences. 107, UNSP 00072. DOI: 10.1051/matecconf/201710700072.

[16] Caban, J. \& Droździel, P. (2020). Traffic Congestion in Chosen Cities of Poland. Scientific Journal of Silesian University of Technology. Series Transport. 108, 5-14. DOI: 10.20858/sjsutst.2020.108.1.

[17] Cernicky, L., Kupculjakova, J., Pal'o, J. \& Kalasova, A. (2020). Reducing delay time at signal controlled junction with the help of actuated control. Advances in Science and TechnologyResearch Journal. 14(3), 149-157. DOI: 10.12913/22998624/122778.

[18] Hudak, M. \& Madlenak, R. (2016). The research of driver's gaze at the traffic signs. In CBU International Conference Proceedings 2016, Innovations in Science and Education. 896-899. DOI: $10.12955 /$ cbup.v4.870.

[19] Jurecki, R.S., Stańczyk, T.L. \& Jaśkiewicz, M.J. (2017). Driver's reaction time in a simulated, complex road incident. Transport. 32(1), 44-54. DOI: 10.3846/16484142.2014.913535.

[20] Raslavičius, L., Keršys, A., Pukalskas, S., Bazaras, J., Jablonskytė, J., Ilgakojytė-Bazarienė, J. \& Makaras, R. (2015). City transport analysis using the General Motors (GM) microscopic model. Public Transport. 7(2), 159-183. DOI: 10.1007/s12469-014-0094-z.

[21] Rievaj, V., Vrábel, J., Synak, F. \& Bartuška, L. (2018). The effects of vehicle load on driving characteristics. Advances in Science and Technology Research Journal. 12(1), 142-149. DOI: 10.12913/22998624/80896.

[22] Poliak, M., Mrnikova, M., Simurkova, P., Medvid, P., Poliakova, A. \& Hernandez, S. (2018). Social law in road transport like tool safety road transport. In XI International ScienceTechnical Conference Automotive Safety, Casta - Papiernicka, 18-20 April 2018, Slovakia, IEEE Proceedings Paper. DOI: 10.1109/AUTOSAFE.2018.8373317.

[23] Kampf, R., Stopka, O., Kubasakova, I. \& Zitricky, V. (2016). Macroeconomic evaluation of projects regarding the traffic constructions and equipment. In World Multidisciplinary Civil Engineering-Architecture-Urban Planning Symposium 2016, WMCAUS 2016. Procedia Engineering 161, 1538-1544. DOI: 10.1016/j.proeng.2016.08.623.

[24] Caban, J. \& Dudziak, A. (2019). Development of a City Bike System on the example of the city of Lublin. LOGI - Scientific Journal on Transport and Logistics 10(2), 11-22. DOI: 10.2478/logi-2019-0011.

[25] Kazemzadeh, K., Laureshyn, A., Hiselius, L.W. \& Ronchi, E. (2020). Expanding the scope of the bicycle level-of-service concept: a review of the Literature. Sustainability. 12(7), 2944. DOI: $10.3390 /$ su12072944. 
[26] Borrato, L., Manca, M., Lugano, G. \& Gogola, M. (2020). Characterizing user behavior in journey planning. Computing. 102(5), 1245-1258. DOI: 10.1007/s00607-019-00775-8.

[27] Kazemzadeh, K., Camporeale, R., D’Agostino, C., Laureshyn, A. \& Hiselius, L.W. (2020). Same questions, different answers? A hierarchical comparison of cyclists' perceptions of comfort: In-traffic vs. online approach. Transportation Letters. 1-9. DOI: 10.1080/19427867.2020.1737373.

[28] Veternik, M. \& Gogola, M. (2017). Examining of correlation between demographic development of population and their travel behaviour. 12th International Scientific Conference of Young Scientists on Sustainable, Modern and Safe Transport, Procedia Engineering. 192, 929-934. DOI: 10.1016/j.proeng.2017.06.160.

[29] Korfant, M. \& Gogola, M. (2017). Possibilities of using traffic planning software in Bratislava. 12th International Scientific Conference of Young Scientists on Sustainable, Modern and Safe Transport, Procedia Engineering. 192, 433-438. DOI: 10.1016/j.proeng.2017.06.075.

[30] Korfant, M. \& Gogola, M. (2019). Traffic generation by various types of urban facilities within Slovak Republic. 13th International Scientific Conference on Sustainable, Modern and Safe Transport (TRANSCOM), Transportation Research Procedia. 40, 310-316. DOI: 10.1016/j.trpro.2019.07.046.

[31] Medvid, P., Gogola, M. \& Kubalak, S. (2020). Occupancy of public transport vehicles in Slovakia. LOGI 2019 - Horizons of Autonomous Mobility In Europe, edited by: Stopkova, M; Bartuska, L; Stopka, O. Transportation Research Procedia. 44, 153-159. DOI: 10.1016/j.trpro.2020.02.022.

[32] Misztal, W. (2019). The impact of perturbation mechanisms on the operation of the Swap Heuristic. The Archives of Automotive Engineering - Archiwum Motoryzacji. 86(4), 27-39. DOI: 10.14669/AM.VOL86.ART2.

[33] Stopka, O. (2020). Draft model of delivery routes at a city logistics scale when applying the Clarke-Wright method. The Archives of Automotive Engineering - Archiwum Motoryzacji. 87(1), 67-80. DOI: 10.14669/AM.VOL87.ART6.

[34] Abdulhamid, M. \& Kinyua, N. (2020). Software for recognition of car number plate. Applied Computer Science. 16(1), 73-84. DOI:10.23743/acs-2020-06.

[35] Gogola, M. (2018). Are the e-bikes more dangerous than traditional bicycles? 11th International Scientific and Technical Conference on Automotive Safety 2018, IEEE Proceedings Paper. DOI: 10.1109/AUTOSAFE.2018.8373344.

[36] Małek, A. \& Taccani, R. (2019). Long-term test of an electric vehicle charged from a photovoltaic carport. The Archives of Automotive Engineering - Archiwum Motoryzacji. 86(4), 55-63. DOI: 10.14669/AM.VOL86.ART4.

[37] Csonka, B., Havas, M., Csiszár, Cs. \& Földes, D. (2020). Operational Methods for Charging of Electric Vehicles. Periodica Polytechnica Transportation Engineering. 48(4), 369-376. DOI: 10.3311/PPtr.15853.

[38] Gogola, M. \& Hocova, M. (2016). Deurbanisation and mobility. Conference: 6th Transport Research Arena (TRA), 2016, Transportation Research Procedia. 14, 1193-1200. DOI: 10.1016/j.trpro.2016.05.190.

[39] Rydzkowski W. \& Wojewódzka-Król K. (2010). Transport. Warsaw, Poland, Polish Scientific Publisher.

[40] Droździel, P., Rybicka, I., Brumercikova, E. \& Bukova, B. (2019). The application of the progressive decision-making methods in the electronic payment system in public transport. Transport Problems. 14(3), 135-144. DOI: 10.20858/tp.2019.14.3.12. 
[41] Szołtysek J. (2011). Creating the mobility of city dwellers. Warsaw, Wolters Kluwer Poland.

[42] Mamcarz, P., Droździel, P., Madleňáková, L., Sieradzki, A. \& Droździel, P. (2019). Level of occupational stress, personality and traffic incidents: Comparative study of public and freight transport drivers. Transportation Research Procedia. 40, 1453-1458. DOI: 10.1016/j.trpro.2019.07.201.

[43] Materials on road investments and mobility in the city for the development of the implementation program of the Low-Emission Economy Plan for the city of Lublin, from http://www.projekty.lublin.eu/sites/default/files/materialy_z_zakresu_inwestycji_drogowych_ i_mobilnosci.pdf.

[44] Ordinance no. 415/2010 of the Mayor of Lublin of June 10, 2010 on the implementation of the "Technical standards for the bicycle infrastructure of the City of Lublin", from http://bip.lublin.eu/.

[45] Resolution No. 224 / XIV / 2011 of the Lublin City Council of 20 October 2011 on the adoption of the "Cycling Policy of the City of Lublin", from http://bip.lublin.eu/.

[46] Resolution No. 260 / XV / 2011 of the Lublin City Council of November 24, 2011 on the adoption of the "Concept for the development of bicycle transport in the city of Lublin", from http://bip.lublin.eu/.

[47] Strategy for the implementation of the bicycle road system in the city of Lublin from 2014. (2020, October). $\quad$ Retrieved October 10, 2020, from https://lublin.eu/download/gfx/lublin/userfiles/_public/lublin/komunikacja/lublin_na_rowerze /dokumenty/strategia_realizacji_systemu_drog_rowerowych_w_miescie_lublin_2014.zip.

[48] Sustainable Mobility Plan for Lublin of 2015, (2015, September). Retrieved October 10, 2020, from

https://lublin.eu/download/gfx/lublin/userfiles/_public/lublin/komunikacja/lublin_na_rowerze /dokumenty/plan_zrownowazonej_mobilnosci_2015.pdf.

[49] The official website of the Lublin City Hall, (2018). Retrieved October 20, 2018, from https://lublin.eu/mieszkancy/partycypacja/mobilnosc-aktywna/lublinrowerowy/infrastruktura-rowerowa/.

[50] Lublin City Bike news, (2020). Retrieved October 10, 2020, from https://lubelskirower.pl/en/news/.

[51] Statistics on the functioning of the Lublin City Bike. (2013). Retrieved October 20, 2020, from https://mirl.info.pl/s/statLRM.

[52] Agarwal, A. \& Kaddoura, I. (2020). On-road air pollution exposure to cyclists in an AgentBased simulation framework. Periodica Polytechnica Transportation Engineering. 48(2), 117 125. DOI: 10.3311/PPtr.15853. 